\title{
Photobiomodulation therapy enhances topical diclofenac absorption in healthy volunteers - a randomized placebo-controlled trial: preliminary results
}

\author{
A terapia de fotobiomodulação aumenta a absorção de diclofenaco tópico em voluntários saudáveis \\ - um ensaio randomizado controlado por placebo: resultados preliminares
}

La terapia de fotobiomodulación mejora la absorción tópica de diclofenaco en voluntarios sanos: un ensayo aleatorizado controlado con placebo: resultados preliminares

Received: 09/10/2021 | Reviewed: 09/17/2021 | Accept: 09/18/2021| Published: 09/19/2021

\author{
Patricia Sardinha Leonardo \\ ORCID: https://orcid.org/0000-0002-7662-7702 \\ Universidade do Vale do Paraíba, Brazil \\ E-mail: patyssardinha@gmail.com \\ Rodrigo Leal de Paiva Carvalho \\ ORCID: https://orcid.org/0000-0002-0147-0122 \\ São Paulo State University, Brazil \\ E-mail: rodcarvalho2002@yahoo.com.br \\ Sergio Gomes da Silva \\ ORCID: https://orcid.org/0000-0002-9650-809X \\ Fundação Cristiano Varella, Brazil \\ E-mail: sgomesilva@hotmail.com \\ Gustavo Duarte Mendes \\ ORCID: https://orcid.org/0000-0001-8700-5709 \\ Metropolitan University of Santos, Brazil \\ E-mail: mendesgd@yahoo.com.br \\ Gilberto De Nucci \\ ORCID: https://orcid.org/0000-0002-4346-7941 \\ State University of Campinas, Brazil \\ E-mail: denucci@gilbertodenucci.com \\ Rodrigo Alvaro Brandão Lopes-Martins \\ ORCID: https://orcid.org/0000-0003-4942-988X \\ Universidade Brasil, Brazil \\ University Anápolis, Brazil \\ E-mail: ralopesmartins@gmail.com
}

\begin{abstract}
The inflammatory Muscle-skeletal disorders are responsible for a high economic impact on public health and Pharmacological treatments produce important renal and gastric toxicity especially. However, the real effects of topical NSAID's still controversial. Photobiomodulation therapy has been used to treat musculo-skeletal conditions. The aim of this study was to evaluate the effects of Photobiomodulation on topical absorption of sodium diclofenac in healthy volunteers. Methods. The volunteers were selected after an assessment of their state of health. The study began with 12 volunteers with dark skin and 12 white skin. The study was designed to determinate the pharmacokinetic parameters. The volunteers received during hospitalization $5 \mathrm{~g}$ diclofenac gel in the presence or not of photobiomodulation, following the randomization. A Laser Cluster with 14 laser diodes (100 mW/diode) delivered 3 Joules of Energy/diode (spot area $0.028 \mathrm{Cm} 2$ ). Blood samples were taken for determination of plasmatic diclofenac concentration $(0.5,1,2,3,4,5,6,7,8,10,12,14,16,18,24 \mathrm{~h})$ by tandem mass spectrometry. Low Power Laser Therapy operating at a wavelength of $650 \mathrm{~nm}$ was effective to enhance the absorption of diclofenac emulgel in whiteskinned individuals but not in black-skinned individuals. Maximum plasma concentrations were higher in the whiteskinned group of volunteers who received low-power laser irradiation prior to drug application when compared to the placebo group.
\end{abstract}

Keywords: Photobiomodulation; Tandem mass spectrometry; Bioavailability; Pharmacokinetics; Laser; Diclofenac.

\section{Resumo}

As doenças inflamatórias musculoesqueléticas são responsáveis por alto impacto econômico na saúde pública e os tratamentos farmacológicos produzem importante toxicidade renal e gástrica principalmente. No entanto, os efeitos reais dos AINEs tópicos ainda são controversos. A terapia de fotobiomodulação tem sido usada para tratar doenças músculo-esqueléticas. O objetivo deste estudo foi avaliar os efeitos da fotobiomodulação na absorção tópica de 
diclofenaco de sódio em voluntários saudáveis. Métodos. Os voluntários foram selecionados após avaliação do seu estado de saúde. $\mathrm{O}$ estudo começou com 12 voluntários com pele escura e $12 \mathrm{com}$ pele branca. O estudo foi desenhado para determinar os parâmetros farmacocinéticos. Os voluntários receberam durante a internação $5 \mathrm{~g}$ de gel de diclofenaco na presença ou não de fotobiomodulação, após a randomização. Um cluster de laser com 14 diodos de laser (100 mW / diodo) entregou 3 Joules de energia / diodo (área do ponto de 0,028 cm2). Amostras de sangue foram coletadas para determinação da concentração plasmática de diclofenaco $(0,5,1,2,3,4,5,6,7,8,10,12,14,16,18$, $24 \mathrm{~h}$ ) por espectrometria de massa em tandem. A terapia a laser de baixa potência operando em um comprimento de onda de $650 \mathrm{~nm}$ foi eficaz para aumentar a absorção de diclofenaco emulgel em indivíduos de pele branca, mas não em indivíduos de pele negra. As concentrações plasmáticas máximas foram maiores no grupo de voluntários de pele branca que recebeu irradiação a laser de baixa potência antes da aplicação do medicamento, em comparação com o grupo de placebo.

Palavras-chave: Fotobiomodulação; Espectrometria de massa; Biodisponibilidade; Farmacocinética; Laser; Diclofenaco.

\section{Resumen}

Los trastornos inflamatorios músculo-esqueléticos son responsables de un alto impacto económico en la salud pública y los tratamientos farmacológicos producen una importante toxicidad renal y gástrica especialmente. Sin embargo, los efectos reales de los AINE tópicos siguen siendo controvertidos. La terapia de fotobiomodulación se ha utilizado para tratar afecciones músculo-esqueléticas. El objetivo de este estudio fue evaluar los efectos de la fotobiomodulación sobre la absorción tópica de diclofenaco sódico en voluntarios sanos. Métodos. Los voluntarios fueron seleccionados después de una evaluación de su estado de salud. El estudio comenzó con 12 voluntarios de piel oscura y 12 de piel blanca. El estudio fue diseñado para determinar los parámetros farmacocinéticos. Los voluntarios recibieron durante la hospitalización $5 \mathrm{~g}$ de gel de diclofenaco en presencia o no de fotobiomodulación, tras la aleatorización. Un grupo de láser con 14 diodos láser (100 mW / diodo) entregó 3 julios de energía / diodo (área del punto 0.028 Cm2). Se tomaron muestras de sangre para la determinación de la concentración plasmática de diclofenaco $(0,5,1,2,3,4,5$, 6 , $7,8,10,12,14,16,18,24$ h) mediante espectrometría de masas en tándem. La terapia con láser de baja potencia que opera a una longitud de onda de $650 \mathrm{~nm}$ fue eficaz para mejorar la absorción del emulgel de diclofenaco en personas de piel blanca, pero no en personas de piel negra. Las concentraciones plasmáticas máximas fueron más altas en el grupo de voluntarios de piel blanca que recibieron irradiación con láser de baja potencia antes de la aplicación del fármaco en comparación con el grupo de placebo.

Palabras clave: Fotobiomodulación; Espectrometría de masas; Biodisponibilidad; Farmacocinética; Láser; Diclofenaco.

\section{Introduction}

Muscle-skeletal disorders (MSD) are the burden of modern society and several treatments have been used to decrease pain, discomfort and improve function especially in acute phase of inflammation to treat the affected tissues (Khan et al, 2000). The treatment options for muscle-skeletal diseases include a wide variety of therapeutic modalities such as drug therapy, phototherapy, cryotherapy, eccentric exercise and others. However, the side effects of anti-inflammatory drugs are quite evident more than never.

We recently demonstrated in experimental studies that the most commonly used NSAID diclofenac presented serious deleterious effects in a rat model of collagenase-induced rat tendinitis, decreasing the elasticity of the tendons and increasing the risk of sudden ruptures (Marcos et al, 2012). The corticosteroids are also widely used to treat MSD and alleviate pain. However, it is noteworthy that corticoids treatments also result in severe side effects both local and systemic. Its use does not appear to provide long term benefits, possibly leading to reduction in strength of the treated tissue (Andres \& Murrel, 2008). Recently, Dean et al (2014) in a Meta-analysis reported that is clear that corticosteroid has significant negative effects on tendon cells in vitro, including reduced cell viability, increased collagen disorganization and necrosis as shown by in vivo studies.

All of these studies have been performed using systemic anti-inflammatory drugs. When used orally, diclofenac, for example, is able to produce gastrointestinal bleeding and ulcers, renal failure and thrombotic events, among others [5,6]. On the other hand, topical NSAID's present very few or undetectable side-effects, but their efficacy is controversial when compared to oral or injectable routes (Banning 2008; McCormack e \& Scott, 2008; Miyatake et al, 2009;). 
Some authors reported that the use of oral NSAIDs for skeletal muscle and joint diseases in muscle and synovial tissues is reasonably established (Miyatake et al, 2009). The authors compared oral and topical pharmacokinetics when administered in recommended dosages. According to these authors, topically applied diclofenac is a valid therapy.

Photobiomodulation Therapy - PBMT - and Drug Absorption

We recently demonstrated in an experimental setup in rats that photobiomodulation was effective to enhance intramuscular as well as topical diclofenac absorption. Besides, there was an additive anti-inflammatory effect of PBMT and topical formulations (De Paiva Carvalho, 2019). The vasodilatation together with the anti-inflammatory properties of PBM support the hypothesis that laser therapy may enhance drug permeation of absorption of topical actives. The light-induced vasodilatation through the increases in cyclic-GMP can possibly be related to nitric oxide release from vascular endothelium or from plasmatic S-linked compounds (Kipshidze et al, 2000). According to Samoilova et al (2008), LLLT increases blood flow of skin microcirculation by $32 \%$ and $45 \%$ in time-dependent manner. The authors also demonstrated that NO-inhibition with LNMMA was capable of inhibiting light-induced vasodilatation). Plass et al (2012) reported that vessels exposed to light source showed a remarkable as well as comparable photorelaxation at definite energy densities and mediated by NO. Taken together, these data suggest that light-induced increases in blood flow can be mediated by the common NO-cGMP pathway and influence drug permeation or absorption. However, there is not a single clinical trial performed to assess the effects of PBM on plasma bioavailability topically applied medicines using tandem mass spectrometry.

\section{Methodology}

This study was conducted in accordance with Good Clinical Practices (BCP) and other recommendations established by ICH, as well as in accordance with Resolutions 196/96 and 251/97 of the National Health Council - Ministry of Health and DRC 103 of 08 May 2003 of the National Agency of Sanitary Surveillance (ANVISA) and complementary Resolutions.

The population studied consisted of healthy volunteers, male adults over 18 years of age (whites and hairless in the dorsal region), with a body mass index greater than or equal to 19 and less than or equal to 28.75 . Volunteers were separated in White-skin Volunteers and Dark-skin Volunteers. The volunteers were recruited among those who present themselves to the Institution for recruitment and selection purposes from the state of São Paulo.

The study is designed to determine the pharmacokinetic parameters (ASC0-Last and Cmax). In this study, such parameters are obtained by determination of plasmatic drug concentrations, based on the application of a non-compartmental model to evaluate these concentrations after topical administration of the drug. Therefore, the primary purpose of the clinical stage is to collect blood samples from volunteers to measure (at the analytical stage) plasma levels of the drug after its topical administration with or without active photobiomodulation in White-skin and dark-skin individuals.

\section{Study Design}

The study was open and randomized, without blind coding procedures. The treatment sequence assigned to each volunteer in the study periods was determined by a randomization list prepared by the researcher. The volunteers (18-55 years; body mass index 19-27) were selected for the study after an assessment of their state of health based on a clinical evaluation and laboratory tests. The study began with 12 volunteers with dark skin and 12 white skin. One volunteer dropped out of the study by personal reasons.

The clinical protocol was approved (CEP1020/2010) by the Ethics Committee of the University of Campinas. Any major changes required approval from the Committee. The study was performed in accordance with the provisions of the Declaration of Helsinki (1964), as revised in Tokyo (1975), Venice (1983), Hong Kong (1989), Somerset West (1996), 
Edimburgo (2000), Washington (2002), Tóquio (2004) and Seoul (2008). All volunteers were healthy as assessed by physical examination, electrocardiogram, and the following laboratory tests: blood glucose, urea, uric acid, creatinine, alkaline phosphatase, aspartase and alanine aminotransferases, gamma-gluthamil transferase, total billirubin, albumin and total protein, trygliceride, total cholesterol, hemoglobin, hematocrit, erythrocyte sedimentation rate, total and differential white cell and platelet counts, and routine urinalysis. All subjects were negative for human deficiency, hepatitis B (except for serological scar) and hepatitis $C$ virus.

After the selection, the volunteers who were considered qualified to participate in this study were hospitalized for approximately 36 hours. The volunteers were hospitalized at 6:00 p.m. having a normal evening meal, and after an overnight fast starting at 10:00 p.m. The volunteers received during hospitalization $5 \mathrm{~g}$ diclofenac gel [CATAFLAM EMULGEL, Novartis Biosciences S.A.] in the presence or not of Laser Irradiation, following the randomization. Water (200 $\mathrm{mL})$ was given immediately after drug administration. All volunteers then fasted for $2 \mathrm{~h}$ following the drug administration, after which a standard breakfast was consumed. A standard lunch and an evening meal were provided $4 \mathrm{~h}$ and $10 \mathrm{~h}$ after dosing, respectively. No other food was permitted during the in-house period. Liquid consumption was permitted ad libitum after lunch but xanthine-containing drinks including tea, coffee, and cola were prohibited. Systolic and diastolic arterial pressure (measured non-invasively with a sphygmomanometer), heart rate and temperature were recorded just before and at 4,8 and 12 sampling collection. After the collection of 24 hours, the volunteers undergone medical evaluation and were dispensed.

\section{Photobiomodulation Parameters}

The subjects of the study were depilated, when necessary, in the dorsal region, in an area of $20 \mathrm{X} 20 \mathrm{Cm}$. Later, they received the application of photobiomodulation using the DMC equipment (Figure 01), At the energy dose of 3 Joules/diode, for a total of 30 seconds of irradiation. The laser cluster consists of 14 diodes (100 mW) with spot area of $0.028 \mathrm{Cm} 2$. After 3 minutes of irradiation, they received the application of diclofenac gel on the delimited region.

Figure 1 - Schematic representation of Laser Cluster with 14 laser diodes with output power of $100 \mathrm{~mW}$ each. Font: DMC Equipments®.

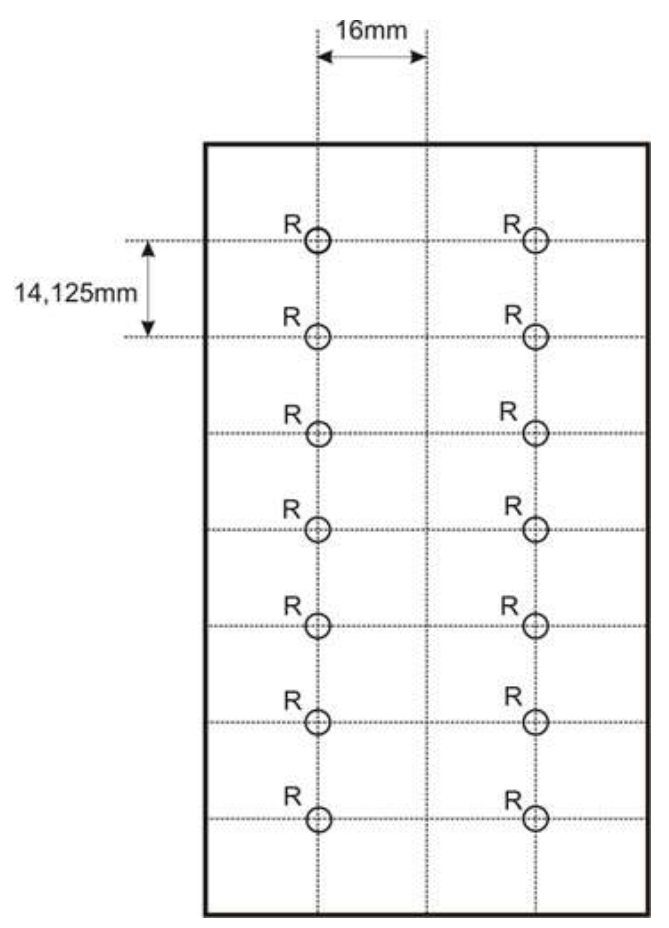

Source: Authors. 


\section{Quantification of Samples}

Stock solutions of diclofenac and IS (Naproxen) were prepared in methanol/water (50:50, v/v) at concentrations of 1 $\mathrm{mg} / \mathrm{mL}$. Diclofenac calibration curves were prepared by spiking blank plasma at concentrations of 10, 20, 60, 200, 500, 1000, 2000 and $4000 \mathrm{ng} / \mathrm{mL}$ and each concentration was analysed in duplicate. The quality control samples were prepared daily in blank plasma at concentrations of 10,30, 800 and $3200 \mathrm{ng} / \mathrm{mL}$. For each validation were analyzed eight for each quality control level (three validations were performed). The spiked plasma samples (standards and quality controls) were extracted in each analytical batch along with blinded samples.

\section{Chemicals and reagents}

Diclofenac was obtained from Farmacopéia Brasileira (Lot 2007, Brazil). Acetonitrile, methanol, diethyl ether and formic acid and acetic acid were purchased from J.T. Baker (USA) and hexane from Mallinckrodt (USA). Blank human blood was collected from healthy, drug-free volunteers. Plasma was obtained by centrifugation of blood treated with sodium heparin. Pooled plasma was prepared and stored at approximately $-20^{\circ} \mathrm{C}$ until needed.

\section{Drug analysis}

The blood samples treated with sodium heparin were centrifuged at approximately 2,000 g for $10 \mathrm{~min}$ at room temperature and the plasma was stored at $-20^{\circ} \mathrm{C}$ until assayed.

The extraction was performed by vortex-mixing $100 \mathrm{uL}$ of each plasma sample, placed in glass tubes followed by the internal standard (50 uL of Naproxen at $3000 \mathrm{ng} / \mathrm{mL}$ ), with $25 \mathrm{uL}$ of formic acid (88\%) and $4 \mathrm{~mL}$ of an organic solvent mixture (hexano/diethyl-ether; 20:80, v/v) for $40 \mathrm{~s}$ in the vortex. This step was done in a fume cupboard. The upper organic phase was transferred to another set of clean glass tubes and evaporated until dry under $\mathrm{N} 2$ at $45{ }^{\circ} \mathrm{C}$. The dry residues were dissolved with $500 \mu \mathrm{L}$ of acetonitrile/water $(50 / 50 ; \mathrm{v} / \mathrm{v})$ and vortex for $10 \mathrm{~s}$. The solution was transferred to 96-well plates with automatic pipettes and disposable tips.

\section{Chromatographic conditions}

An aliquot (10 uL) of each plasma extract was injected into a Genesis C8 analytical column (4 um, 150 x $4.6 \mathrm{~mm}$ i.d.). The compounds were eluted by pumping the mobile phase at a flow rate of $1200 \mathrm{uL} / \mathrm{min}$. Under these conditions, typical standard retention times were $2.06 \mathrm{~min}$ for diclofenac and $1.78 \mathrm{~min}$ for Naproxen, and back-pressure values of approximately 60 bar and split $1 / 6$ were observed. The temperature of the auto-sampler was maintained at $8^{\circ} \mathrm{C} \pm 2$ and the run-time was 2.8 min. The method has an additional time $(0.5 \mathrm{~min})$ to inject a new sample since the autosampler we have employed takes 0.5 min to inject a sample. This additional time is enough to finish the equilibrium between injections. The mobile phase was acetonitrile/water $(80 / 20 ; \mathrm{v} / \mathrm{v})$ and $1 \mathrm{mM}$ of acetic acid.

\section{Mass-spectrometric conditions}

The mass spectrometer (API 3000) operated in negative electrospray ionization mode using a crossflow counter electrode (ES+) was set up for Multiple Reaction Monitoring (MRM) to monitor the transitions $316.0>270.0$ and $285.1>$ 193.2, for diclofenac and the internal standard, respectively. To optimize all of the MS parameters, a standard solution of the analyte and internal standard was infused into the mass spectrometer. For both diclofenac and Naproxen, the following optimized parameters were obtained: for diclofenac the dwell time, cone voltage and collision energy were $300 \mathrm{~ms},-21 \mathrm{~V}$ and $16 \mathrm{eV}$, respectively. The corresponding values for Naproxen were $300 \mathrm{~ms},-21 \mathrm{~V}$ and $-8 \mathrm{eV}$, respectively. Data acquisition and analysis were performed using the software Analyst $\mathrm{v}(\mathrm{v}$ 1.4). 


\section{Method development}

The mass spectrometer was set as follows: m/z 294.06 for diclofenac and 229.11 for Naproxen as the precursor ions and $\mathrm{m} / \mathrm{z} 250$ and 185 as the respective product ions in the MRM mode. Linearity, precision and accuracy were determined to assess the performance of the method. Linearity was determined to assess the performance of the method. A linear leastsquares regression with a weighting index of $1 / x 2$ was applied to the peak area ratios of diclofenac and internal standard vs. the concentrations of the plasma standards of diclofenac in duplicate to generate a calibration curve.

The recovery was evaluated by dividing the extracted sample mean response by the unextracted (spiked blank plasma extract) sample mean of the corresponding concentration. The matrix effect experiments were carried out using the ratio between spiked mobile phase solutions and unextracted samples, spiked on plasma residues. Within- and between-run precision were determined as the coefficient of variation, $(\mathrm{CV})(\%)=100(\mathrm{SD} / \mathrm{M})$ and the accuracy $(\%)$ by $100(\mathrm{M} / \mathrm{T})$, where $\mathrm{M}$ is the mean, $\mathrm{SD}$ is the standard deviation of $\mathrm{M}$, and $\mathrm{T}$ is the theoretical concentration.

\section{Stability}

To assess stability, quality control plasma samples (30 and $3000 \mathrm{ng} / \mathrm{mL})$ were subjected to short-term $(6.7 \mathrm{~h})$ incubation at room temperature; four freeze/thaw $\left(20^{\circ} \mathrm{C}\right)$ cycles; $52 \mathrm{~h}$ in the autosampler $\left(8^{\circ} \mathrm{C} \pm 2\right)$; and a long-term incubation (73 days). Subsequently, the diclofenac concentrations were measured and compared with freshly prepared samples.

\section{Pharmacokinetic Parameters}

Evaluation between the two situations was assessed by calculating individual test/reference ratios for the peak of concentration (Cmax), the area under the curve (AUC) of the plasma concentration until 24hours (AUC0-24h). The Cmax and the time taken to achieve this concentration (Tmax) were obtained directly from the curves. The software used included WinNonLin Professional Network Edition (Scientific Consulting, v. 3.0), Instat 3.06, Microsoft Excel (v. 7.0) and GraphPad Prism (v. 3.02).

\section{Results}

The formulation was well tolerated at the administered doses and no significant adverse reactions were observed or reported. The biochemical parameters presented no clinically relevant alterations. One volunteer dropout of the study by personal reasons after the first period of the administration.

The chromatogram of the standard LOQ sample showed that the retention times for diclofenac were $2.06 \pm 0.3 \mathrm{~min}$ and $1.78 \pm 0.3 \mathrm{~min}$ for the IS. The calibration curves (for diclofenac) showed good linearity ( $\mathrm{r} 2>0,998700)$ within the range 10 to $4000 \mathrm{ng} / \mathrm{mL}$ for analyte. The lower limit of quantification (LOQ), defined as the lowest concentration at which both precision and accuracy were less than or equal to $20 \%$, was $10 \mathrm{ng} / \mathrm{mL}$ for both diclofenac.

\section{Area under Curve}

Figure 2 demonstrates the Area Under Curve values for diclofenac emulgel plasma bioavailability curve applied topically to the back of healthy white-skinned and Black-skinned volunteers following the application of Laser radiation or Placebo Laser. We can observe a significant enhancement of AUC after active laser application in White-skinned volunteers but not for the black-skinned volunteers. 
Figure 2 - Area under the curve of plasmatic concentration of Topical diclofenac in 12 white skin and 12 dark skin volunteers submitted to previous active or placebo Laser irradiation.

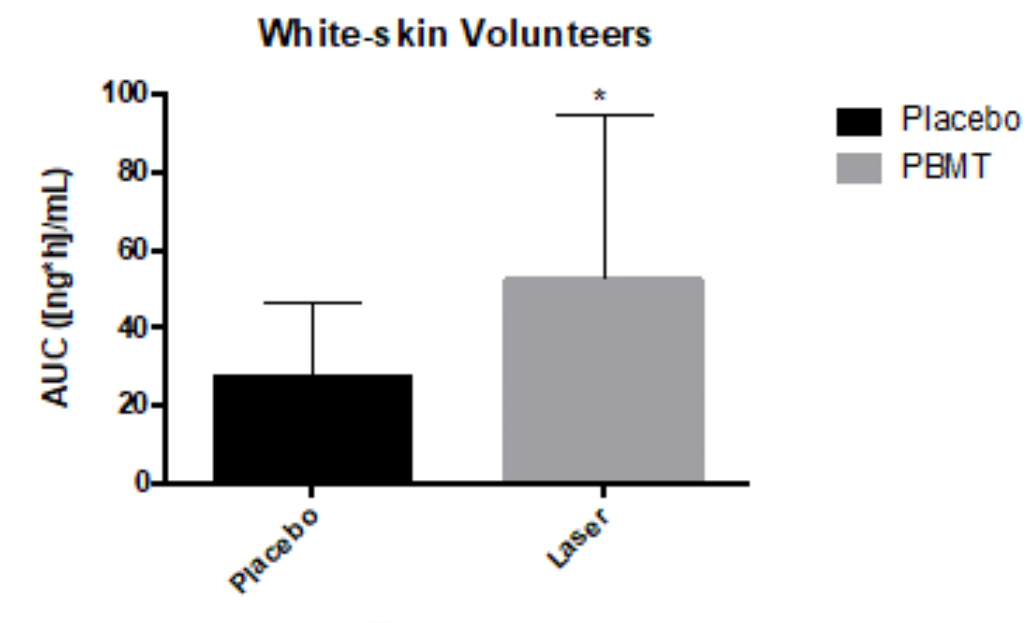

Treatments

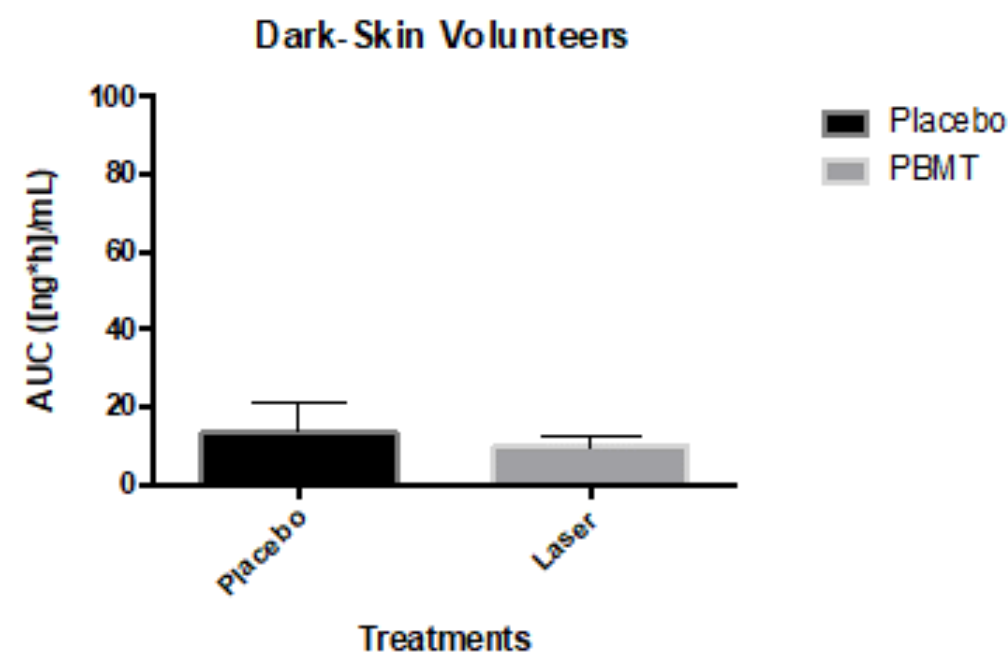

Source: Authors.

\section{Maximal Diclofenac Plasmatic Concentration}

Figure 3 demonstrates the maximum plasma concentration values of diclofenac emulgel applied topically to the dorsal region of White and Black-skinned volunteers. We notice that a significant potentiation of Cmax after active laser application in White skin but no significant difference between Cmax after active laser application when compared to Placebo in black skin. 
Figure 3 - Cmax values of diclofenac emulgel in black-skinned volunteers. Values expressed in (ng / $\mathrm{mL}$ ), representing the mean + Standard Deviation of 12 volunteers. $*=p<0.05$.

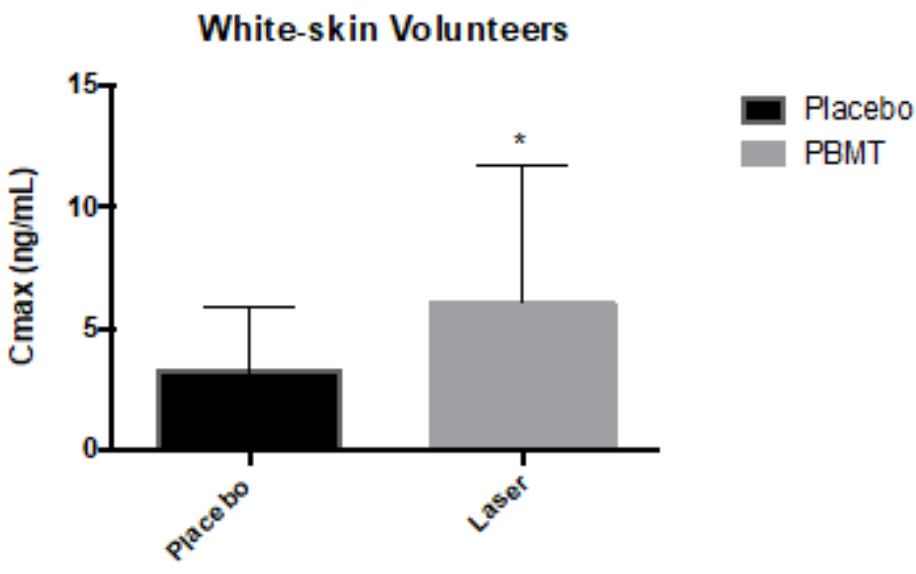

Treatments

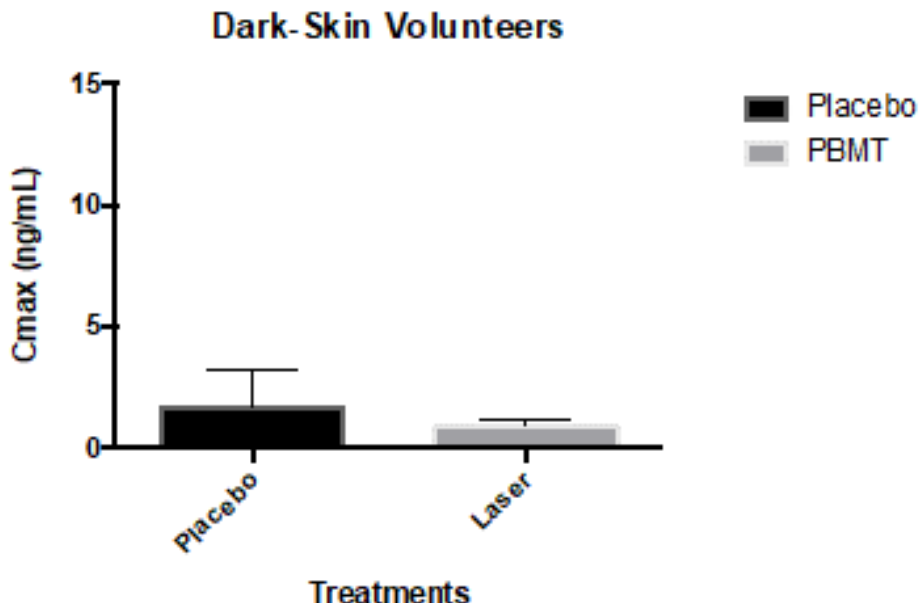

Source: Authors.

Figure 4 shows the comparative values of the maximum plasma concentration of diclofenac emulgel applied topically to white and black skin types after the application of active Laser or Placebo Laser. We can see that white-skinned volunteers had higher Cmax values, even in the placebo group, when compared to black-skinned volunteers. 
Figure 4 - Comparative analysis of plasmatic concentrations of active X Placebo Laser in White X Dark skin volunteers. Values expressed in $(\mathrm{ng} / \mathrm{mL})$, representing the mean + Standard Deviation of 12 volunteers. $*=\mathrm{p}<0.05$.

\section{Diclofenac Plasmatic Concentration}

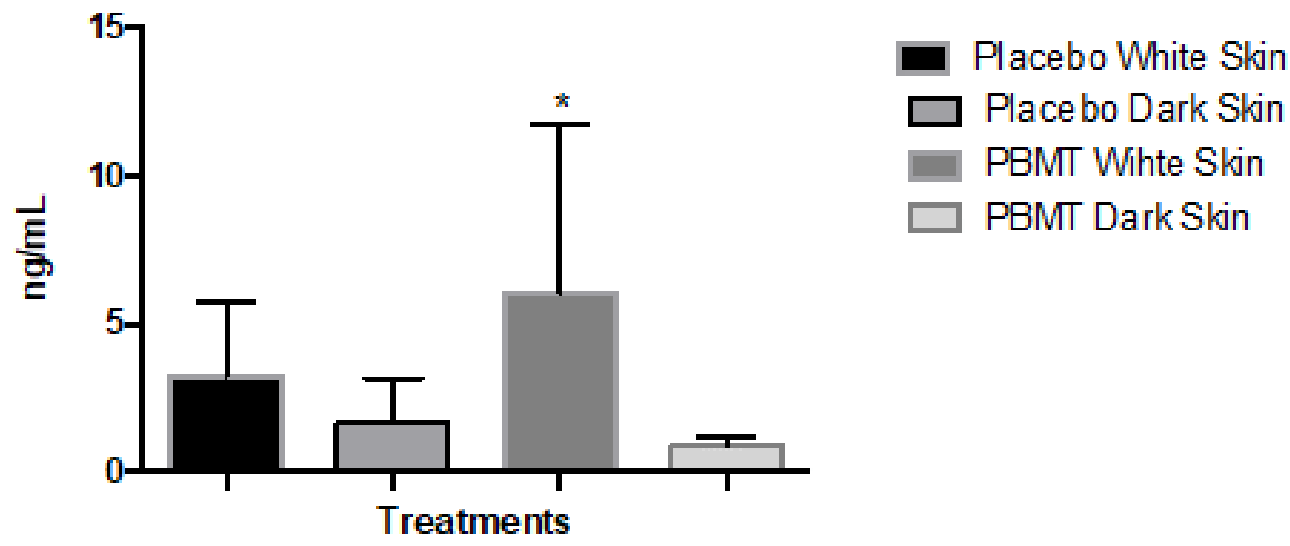

Source: Authors.

Pharmacokinetic Profile of Diclofenac Emulgel Applied Topically to Healthy White-Skinned Volunteers After Low Power Laser and Placebo Laser Irradiation

Figure 5 shows Pharmacokinetic Profile of Diclofenac Emulgel Applied Topically to Healthy White-Skinned Volunteers After laser photobiomodulation and Placebo Irradiation. We can observe the significant potentiation of plasma bioavailability in the group that received the active laser, when compared to the placebo group.

Figure 5 - Plasma bioavailability characteristic curve of diclofenac emulgel applied topically to healthy white skin volunteers after irradiation with Low Power Laser or Placebo Laser.

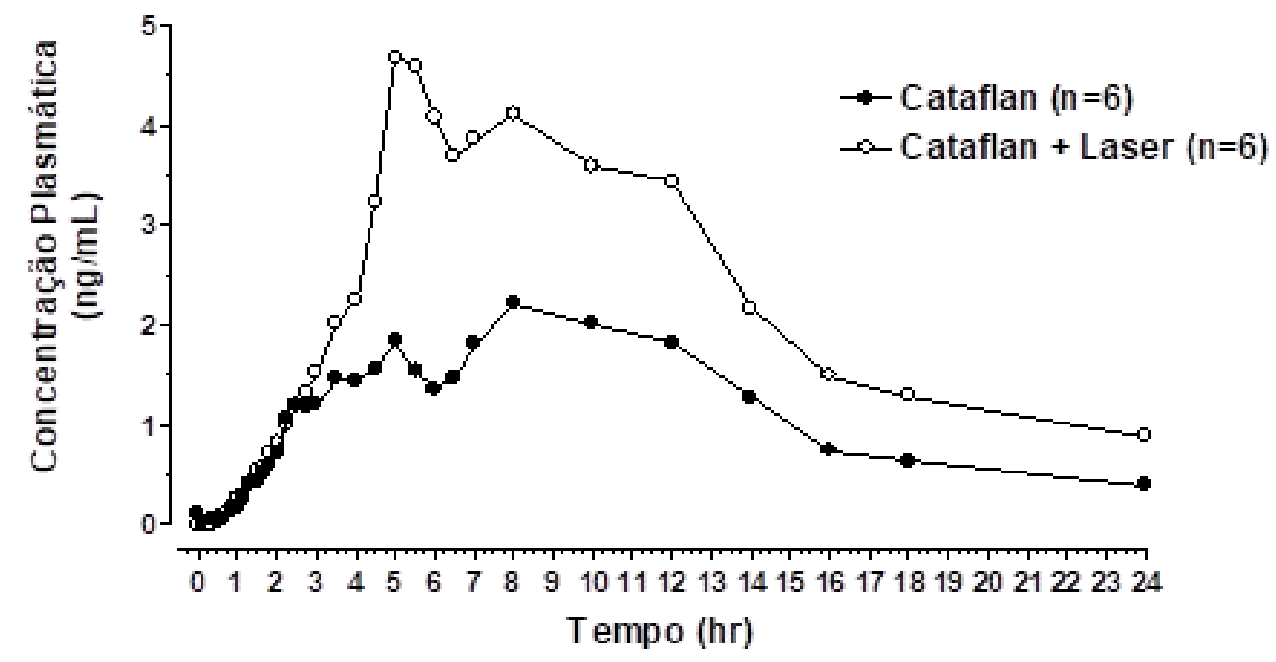

Source: Authors.

Pharmacokinetic Profile of Diclofenac Emulgel Applied Topically to Healthy White-Skinned Volunteers After Low Power Laser and Placebo Laser Irradiation 
Figure 6 shows Pharmacokinetic Profile of Diclofenac Emulgel Applied Topically to Black Skinned Healthy Volunteers After Low Power Laser and Placebo Laser Irradiation. We can observe that there was no significant potentiation of Cmax. As for the plasma bioavailability in the group receiving the active laser there was an increase but not significant when compared to the placebo group.

Figure 6 - Characteristic bioavailability behaviour of topical diclofenac gel healthy black-skinned volunteers after low power or Placebo laser irradiation.

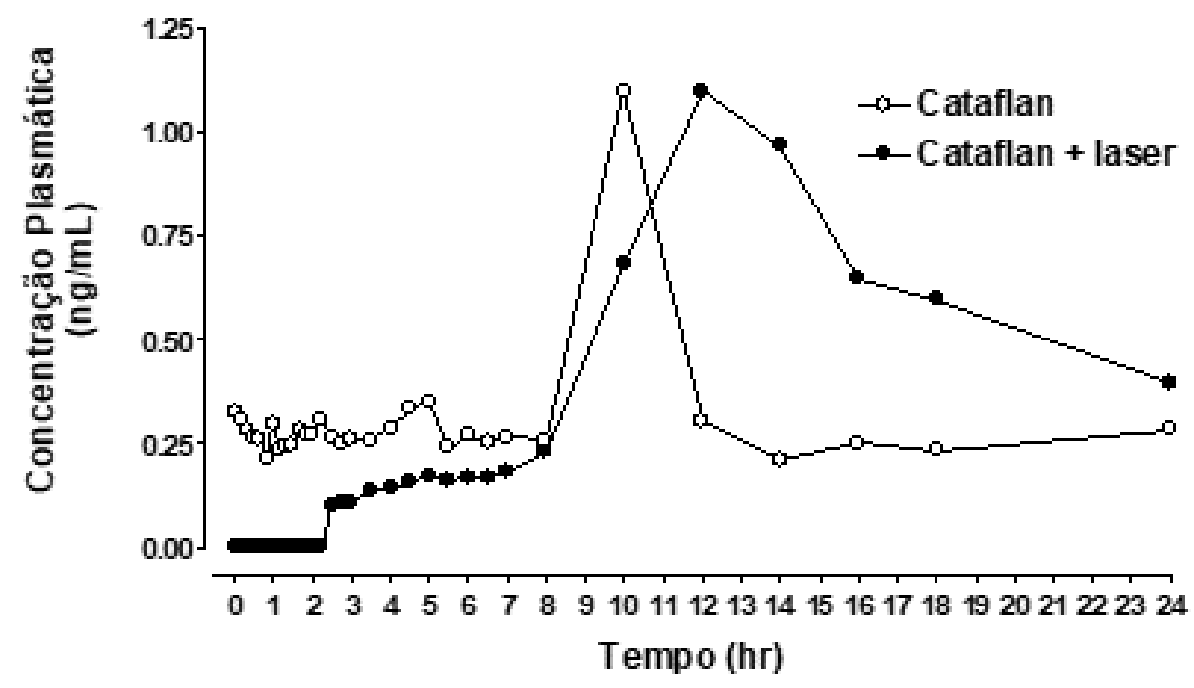

Source: Authors.

\section{Discussion}

In this work we studied the effects of photobiomodulation (PBM) using Laser irradiation operating in the spectral region of red on the pharmacokinetics of topical NSAIDs (diclofenac emulgel) in healthy white and black skin volunteers.

PBM has important modulatory effects, especially in diseases with important inflammatory components. The main purpose of PBM in inflammatory diseases are the inhibition or even reduction / acceleration of inflammatory process resolution as well as the repair of biological tissue and, when possible, the restoration of functional tissue characteristics.

As we mentioned previously, the use of both hormonal (glucocorticoid) and non-hormonal anti-inflammatory drugs in musculoskeletal inflammatory diseases is a major problem for the Health System, due to the high occurrence of serious adverse effects resulting from prolonged use of these drugs. Among the remarkable side-effects of NSAIDs include gastrointestinal bleeding and ulcers, kidney failure and thrombotic events besides the local affected structures. In this context, topical medicines have been of greater interest lately. According to Bjordal et al (2007), among the antiinflammatory drugs used for knee osteoarthritis pain, topical antiinflammatory drugs had a superior effect than systemic drugs. In view of the above, topical anti-inflammatory drugs presenting less side-effects could be an alternative to old drugs.

Currently, pharmaceutical companies increased their efforts to improve the transdermal permeation or absorption of active principles. However, studies combining electrophysical agents such as Laser irradiation with topical drugs are rare, as are differences or particularities of skin types and drug absorption. We recently demonstrated in an experimental setup of rat muscle trauma that photobiomodulation potentiated diclofenac absorption, and also presented synergistic effect of laser associated with topical drug (De Paiva Carvalho et al, 2019).

Other devices have been employed to enhance drug permeation or absorption of such as chemical agents, immersion, 
microneedles and ultrasound, but in some drugs none of them can satisfactorily overcome the stratum corneum (SC) barrier (Gomez et al, 2008). Stratum corneum (SC) is an specialized region of epidermis and is the outermost layer of our skin. SC has as one of its functions to act as a barrier against infections. This layer is made up of keratinocytes (in this layer they are called corneocytes) which are considered a deposit of keratin (cells without nuclei and unviable) removed by peeling, having a thickness around $0.04 \mathrm{~mm}$ (Egelrud 2000).

Some high-powered light sources were assayed in order to study the facilitation of drug absorption and penetration through SC more effectively and without causing tissue damage such as $\mathrm{CO}$, Nd: YAG lasers and also IPL (intensed pulsed) lasers. light). However, such studies do not evaluate the plasma bioavailability of the drugs used. In several in vitro and in vivo studies, laser application has shown a great ability to improve drug and substance penetration through SC without causing skin damage, demonstrated by analysis such as optical coherence tomography, VIS-NIR fiber spectrometer, spectrophotometer, spectral scanner etc (Gomez et al, 2008; Egelrud 2000; Liu et al, 2010;) . However, the effects appear to be due to structural changes caused by the high power laser.

Laser photobiomodulation has as some of its features the supposed increase of local microcirculation, vasodilation and the recruitment of collateral vascularization. However, studies that demonstrate this property are still scarce, and most use indirect effects. However, these characteristics are widely accepted in view of older studies of muscle tissue, scarring, skin flaps, etc (Kami et al, 1985; Miro et al, 1989; Maegawa et al, 2000; Ivandic et al, 2008;), which could determine the potentiation of the absorption of drugs or other substances.

Our pharmacokinetic and bioavailability results corroborate the above-mentioned study, especially for white-skinned volunteers. This group showed a significant potentiation of pharmacokinetic parameters when irradiated with active laser. On the other hand, black-skinned volunteers had no such effect. In addition, quantified diclofenac levels in black-skinned volunteers were significantly lower when compared to white-skinned volunteers.

In skin pigmentation, the differences are not due to variation in the number of melanocytes, since they do not present significant quantitative differences between black and white skin. The differences are in the properties and quality of melanosomes, such as their type, shape and color, and their distribution in melanocytes and keratinocytes (Batistela et al, 2007; Miot et al, 2009; ).

The main factors that differentiate black from white skin are related to the size, morphology, distribution and degree of melanization of melanosomes (Miot et al 2009). In black skin, melanosomes are larger and larger, in addition to higher activity and maturation rates. Black skin melanosomes, besides containing larger amounts of total melanin and eumelanine, are surrounded by a membrane and are scattered in the cytoplasm of keratinocytes. Due to their size, degradation in keratinocytes is delayed, reaching the intact corneal layer (Miot eet al, 2009).

On the other hand, white skin melanosomes present in smaller amounts, smaller size, low amount of melanin and remain in groups within the keratinocytes and all are surrounded by a single membrane. These melanosomes before reaching the surface layers are destroyed (Batistela et al, 2007).

Referring to the average thickness of the corneal layer, there are no differences between black and white skin. However, Britz et al (2004) found that there are a greater number of SC layers in black skin. Black skin appears to have 22 cell layers in SC, in contrast to white skin that has only 17 layers. Also Like black skin, it has a high intercellular cohesion favoring a greater junction between the layers, but showing no differences in the final thickness. These studies may explain the results obtained in this study, where black-skinned volunteers showed less absorption of diclofenac emulgel, as well as the lack of effect against low power laser irradiation.

Regarding the effects observed for white-skinned volunteers, kipshidze et al (2000), reported that visible ultraviolet light was able to induce vasodilatation with cGMP elevation. As we mentioned before, there are evidences that light sources, 
specially red and infrared wavelengths are capable to induce NO-dependent vasodilatation resulting in hypotensive effects of photobiomodulation. Besides, In vivo animal experiments have shown significant induction of iNOS after laser irradiation in rabbit iliac artery, and according to our results, if laser irradiation raises cGMP levels, a significant local vasodilation could possibly be occurring, thus facilitating the abortion of the topical drug.

\section{Conclusion}

Our study raises important questions, and new data that needs further study such as: a) Determine the mechanism of action responsible for the greater topical absorption of the drug as a result of photobiomodulation in white skin; • Study the differences in drug absorption on different skin types; b) Determine the vascular effects of laser irradiation;

Thus, further studies are necessary to elucidate numerous questions arising from our original study. Laser photobiomodulation operating at a wavelength of $650 \mathrm{~nm}$ was effective to enhance the absorption of diclofenac emulgel in white-skinned individuals but not in black-skinned individuals. Maximum plasma concentrations were higher in the whiteskinned group of volunteers who received photobiomodulation therapy prior to drug application when compared to the placebo group. Additional studies are needed to explain the observed differences between skin types.

\section{References}

Andres, B. M., \& Murrell, G. A. (2008) Treatment of tendinopathy: what works, what does not, and what is on the horizon. Clin Orthop Relat Res. 466(7):1539-54.

Banning M. (2008) Topical diclofenac: clinical effectiveness and current uses in osteoarthritis of the knee and soft tissue injuries. Expert Opin Pharmacother. 9(16):2921-9.

Batistela, M. A., Chorilli, M., \& Leonardi, G. R. (2007) Abordagens no estudo do envelhecimento cutâneo em diferentes etnias. Revista Bras. Farmácia, $88(2), 59-62$.

Bjordal, J. M., Klovning, A., Ljunggren, A. E., \& Slørdal, L. (2007) Short-term efficacy of pharmacotherapeutic interventions in osteoarthritic knee pain: A meta-analysis of randomised placebo-controlled trials. Eur J Pain. 11(2):125-38.

de Paiva Carvalho, R. L. Leonardo, P. S. L. M., Mendes, G. D. Lima, F. P., Lima, M. O., Marcos, R. L., \& Lopes-Martins, R. A. B. (2019) Pharmacokinetic and Pharmacodynamics of Sodium Diclofenac (Topical and IM) Associated with Laser Photobiomodulation on Skeletal Muscle Strain in Rats. International Journal of Photoenergy, 1-12.

Dean, B. J., Lostis, E., Oakley, T., Rombach, I., Morrey, M. E., \& Carr, A. J. (2014) The risks and benefits of glucocorticoid treatment for tendinopathy: a systematic review of the effects of local glucocorticoid on tendon. Semin Arthritis Rheum. 43(4):570-6.

Egelrud, T. (2000) Desquamation in the Stratum Corneum. Acta Derm Venereol; Supp 208: 44-45.

Gómez, C., Costela, A., García-Moreno, I., Llanes, F., Teijón, J. M., \& Blanco, M. D. (2008) Laser treatments on skin enhancing and controlling transdermal delivery of 5-fluorouracil. Lasers Surg Med. 40(1):6-12.

Ivandic, B. T., \& Ivandic, T. (2008) Low-level laser therapy improves vision in patients with age-related macular degeneration. Photomed Laser Surg. 26(3):241-5.

Kami, T., Yoshimura, Y., Nakajima, T., Ohshiro, T., \& Fujino, T. (1985) Effects of low-power diode lasers on flap survival. Ann Plast Surg. $14(3): 278-83$.

Khan, K. M., Cook, J. L., Maffulli, N., \& Kannus, P. (2000) Where is the pain coming from in tendinopathy? It may be biochemical, not only structural, in origin. Br J Sports Med. 34(2):81-3.

Kipshidze, N., Petersen, J. R., Vossoughi, J., Nikolaychik, V., Bakhutashvili, I., Roubin, G. S., Leon, M. B., \& Moses, J. W. (2000) Low-power laser irradiation increases cyclic GMP synthesis in penile smooth muscle cells in vitro. J Clin Laser Med Surg. 18(6):291-4.

Liu, C., Zhi, Z., Tuchin, V. V., Luo, Q., \& Zhu, D. (2010) Enhancement of skin optical clearing efficacy using photo-irradiation. Lasers Surg Med. 42(2), 13240 .

Maegawa,Y., Itoh, T., Hosokawa, T., Yaegashi, K., \& Nishi, M. (2000) Effects of near-infrared low-level laser irradiation on microcirculation. Lasers Surg Med. 27(5), 427-37.

Marcos, R. L., Leal-Junior, E. C., Arnold, G., Magnenet, V., Rahouadj, R., Wang, X., Demeurie, F., Magdalou, J., de Carvalho, M. H., \& Lopes-Martins, R. Á. (2012) Low-level laser therapy in collagenase-induced Achilles tendinitis in rats: analyses of biochemical and biomechanical aspects. $J$ Orthop Res. 30(12):1945-51. 10.1002/jor.22156. 
Research, Society and Development, v. 10, n. 12, e265101220448, 2021

(CC BY 4.0) | ISSN 2525-3409 | DOI: http://dx.doi.org/10.33448/rsd-v10i12.20448

McCormack, P. L., \& Scott, L. J. (2008) Diclofenac sodium injection (Dyloject): in postoperative pain. Drugs. 68(1):123-30. Review. Erratum in: Drugs. 2008; 68(6):801

Miot, L. D. B. (2009) Fisiopatologia Do Melasma. In: Anais Bras. Dermatologia, 84(6), 623-635.

Miro, A. M., Shivaram, U., \& Finch, P. J. (1989) Noncardiogenic pulmonary edema following laser therapy of a tracheal neoplasm. Chest. 96(6):1430-1.

Miyatake, S., Ichiyama, H., Kondo, E., \& Yasuda, K. (2009) Br J Clin Pharmacol. 67(1):125-9. Randomized clinical comparisons of diclofenac concentration in the soft tissues and blood plasma between topical and oral applications.

Plass, C. A., Loew, H. G., Podesser, B. K., \& Prusa, A. M. (2012) Light-induced vasodilation of coronary arteries and its possible clinical implication. Ann Thorac Surg.93(4):1181-6. 10.1016/j.athoracsur.2011.12.062.

Samoilova, K. A., Zhevago, N. A., Petrishchev, N. N., \& Zimin, A. A. (2008) Role of nitric oxide in the visible light-induced rapid increase of human skin microcirculation at the local and systemic levels: II. healthy volunteers. Photomed Laser Surg. 26(5):443-9.

Stanos, S. P. (2007) Topical agents for the management of musculoskeletal pain. J Pain Symptom Manage. 33(3):342-55. 